\title{
Rising Violence against Muslims in India Under Modi and BJP Rule
}

\author{
CJ WERLEMAN
}

Independent Researcher

ORCID No: 0000-0002-0123-9764

ABSTRACT While communal violence has been an ongoing and unfortunate reality for post-colonial and post-partition India, there's no sidestepping the fact that attacks and hate crime incidences against the country's Muslim minority by members of the Hindu majority have occurred in greater frequency and ferocity in the years since Prime Minister Narendra Modi, leader of the Bharatiya Janata Party (BJP), came to power in 2014 -on the back of a Hindu nationalist agenda, one in which anti-Muslim animus and discrimination features in mainstream political discourse and government policy. These realities have brought Muslims to the brink of genocide in India and Kashmir. 


\section{Introduction}

N arendra Modi was sworn in as India's $14^{\text {th }}$ Prime Minister on May 26, 2014, after promising to revitalize the Indian economy and implement the same kind of economic policies that had transformed his home state of Gujarat, where he was Chief Minister from 2001 to 2014.

Largely overlooked by the mainstream Indian media during the 2014 national election campaign, however, was the role Modi played in inciting the Gujarat Riots, which left upwards of 2,000 people dead, ${ }^{1}$ a majority of whom were Muslim. The communal violence began when Modi falsely accused Pakistani secret services of the deaths of 58 Hindu pilgrims aboard a train that caught fire in Godhra station on February 27, 2002, after returning from Ayodhya. ${ }^{2}$ Over the course of several bloody months, 1,679 homes, 1,965 shops, 21 warehouses, and 76 religious shrines were destroyed, the great majority belonging to Muslims. ${ }^{3}$ Hindu ringleaders even boasted of slitting open the wombs of pregnant Muslim women to murder unborn fetuses. ${ }^{4}$

More troubling still was the role played by police officers, who responded to Modi's 'shoot-on-sight' orders by shooting indiscriminately into crowds of Muslim protesters, with Modi later defending their actions by saying they had 'mowed down people' to suppress the violence. ${ }^{5}$ A survivor provided Human Rights Watch with the following testimony:
We were able to handle the crowd but when the police joined in then we couldn't stop them. Our spirit was broken. They were shouting, "Kill them, cut them, look for $\mathrm{Mi}$ yabhai [Muslim man]." The police burned the houses with their own hands. They also looted. Now everyone is afraid of the police; they were only firing on Muslims. They were not firing for riot control. ${ }^{6}$

India's mainstream media may have turned a blind eye to Modi's culpability for the riots during the 2014 national elections, the United States government did not, however, denying him a visa to enter the United States in 2005 on religious-freedom grounds, stemming from credible allegations he had tacitly supported the Hindu extremists responsible for the bloodshed, ${ }^{7}$ and while the Indian Supreme Court ultimately absolved the former Gujarat Chief Minister in 2012, it's worth remembering that the same court declared in 2003 that the riots took place 'with the deliberate connivance and support' of Modi's government. ${ }^{8}$

Not long after his inauguration as Prime Minister, however, it became evident that Modi's neoliberal economic policies were not producing the results he and the BJP ruled the government had hoped, with the Indian economy not only growing at the slowest rate in decades and with unemployment at an all-time high but also with economists describing the Modi economy a 'shattered mess.'

To divert attention away from his government's mismanagement of 
the economy, Modi and BJP leaders turned towards increasingly hostile rhetoric and policies against the country's 200 million Muslim citizens, embracing Hindu majoritarian and exclusivist politics to corral voters and hold power. ${ }^{10}$

This Hindu nationalism is driven by a Hindutva ideology, with both BJP and its right-wing paramilitary sidekick Rashtriya Swayamsevak Sangh (RSS), aiming to unite the Hindu majority to form a Hindu nation, one that excludes non-Hindu minorities. Founded in 1925, RSS sought to inspire a revolution against British colonial rule but without cooperation from Muslims, who its founder Kashav Baliram Hedgewar, a doctor from the city of Nagpur, referred to as 'anti-national' and 'yavana snakes.'11 It was a disciple of Hedgewar that assassinated Mahatma Gandhi in 1948 for cooperating with Muslims.

RSS would draw inspiration from fascist movements in Europe, particularly the Nazi Party of Germany, which it openly praised for advocating racial and ethnic purity. In 1931, when Balakrishna Shivram Moonje, a Hindu nationalist mentor of Hedgewar returned home after meeting with fascist Italian dictator Benito Mussolini in Rome, he called upon Hindu nationalist leaders to:

Imitate the youth movements of Germany and the Balilla and Fascist organisations of Italy. I think they are eminently suited for introduction in India, adapting them to suit the special conditions. I have been

\section{RSS would draw inspiration} from fascist movements in Europe, particularly the Nazi Party of Germany, which it openly praised for advocating racial and ethnic purity

very much impressed by these movements and I have seen their activities with my own eyes in all details. ${ }^{12}$

Today, admiration for fascist movements and Nazism in particular, which is often reframed with a genocidal hatred for Muslims is "rampant in the Hindu nationalist camp" and "has never been as mainstream as it is now," according to famous Indian filmmaker Srenik Rao. ${ }^{13}$ The popularity of Hitler and Nazism within Hindu nationalist culture is easily observable, with Hitler and Nazi paraphernalia common and widespread, along with Hitler themed restaurants, cafes, bars, and clothing

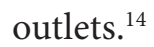

When Modi was the Chief Minister of Gujarat in 2004, school textbooks published by the state under his control portrayed Hitler as a savior of the German people and included chapter titles, "Hitler, the Supremo," and "Internal Achievements of Nazism," with a section on the "Ideology of Nazism" reading, "Hitler lent dignity and prestige to the German government. He adopted the policy of opposition towards the Jewish people and advo- 


\section{Mr. Shah routinely refers}

to Muslim migrants as

'infiltrators' and 'termites,' and

has promised to pick them up

'one by one and throw them

into the Bay of Bengal' cated the supremacy of the German race." 15

This Nazification of the Hindu nationalist agenda has BJP leaders and RSS office-bearers openly calling for the deportation and annihilation of non-Hindu minorities, including Rajeshwar Singh who declared, "Our target is to make India a Hindu Rashtra by 2021. The Muslims and Christians don't have any right to stay here...So they would either be converted to Hinduism or forced to run away from here." 16

Others, including Ranjit Bahadur Srivastava, a BJP leader in Yoji Raj, have threatened Muslims that if they don't vote for BJP, they must prepare themselves for dire consequences, saying: "If you vote for BJP, you will be happy, else you will have to face problems." ${ }^{17}$ And in 2020, a BJP legislator in Uttar Pradesh called for a state-wide boycott of Muslim-owned businesses. ${ }^{18}$

Both BJP and RSS have made no secret of their goal to make life in India so unbearable for Muslims that will have no other choice other than to self-deport to neighboring Paki- stan or Bangladesh. ${ }^{19}$ The Modi government has backed this objective up with a pair of anti-Muslim laws known separately as the Citizenship Amendment Act (CAA) and the National Register of Citizens (NRC).

The Modi government achieved passage of the CAA on December 12, 2019, marking the first time in the country's history the Indian government has made religion the basis for granting citizenship. The law specifically fast-tracks claims of non-Muslim migrants from neighboring Muslim majority countries Pakistan, Bangladesh, and Afghanistan, while the NRC aims to identify and deport millions of undocumented Muslim migrants who have lived in India for decades and generations, ${ }^{20}$ which has "led to fears that millions of Indian Muslims, including many families who have lived in the country for generations, could be stripped of their citizenship rights and disenfranchised," according to Human Rights Watch. ${ }^{21}$

The government has established foreigner tribunals and constructed a network of detention facilities in Assam, where millions of Muslim migrants live, most in impoverished conditions, to accommodate for the mass detention of undocumented Muslim families. ${ }^{22}$ According to The New York Times, "Hundreds of people have been arrested on suspicion of being a foreign migrant -including a Muslim veteran of the Indian Army."23

Members of Modi's government have admitted these laws specifically tar- 


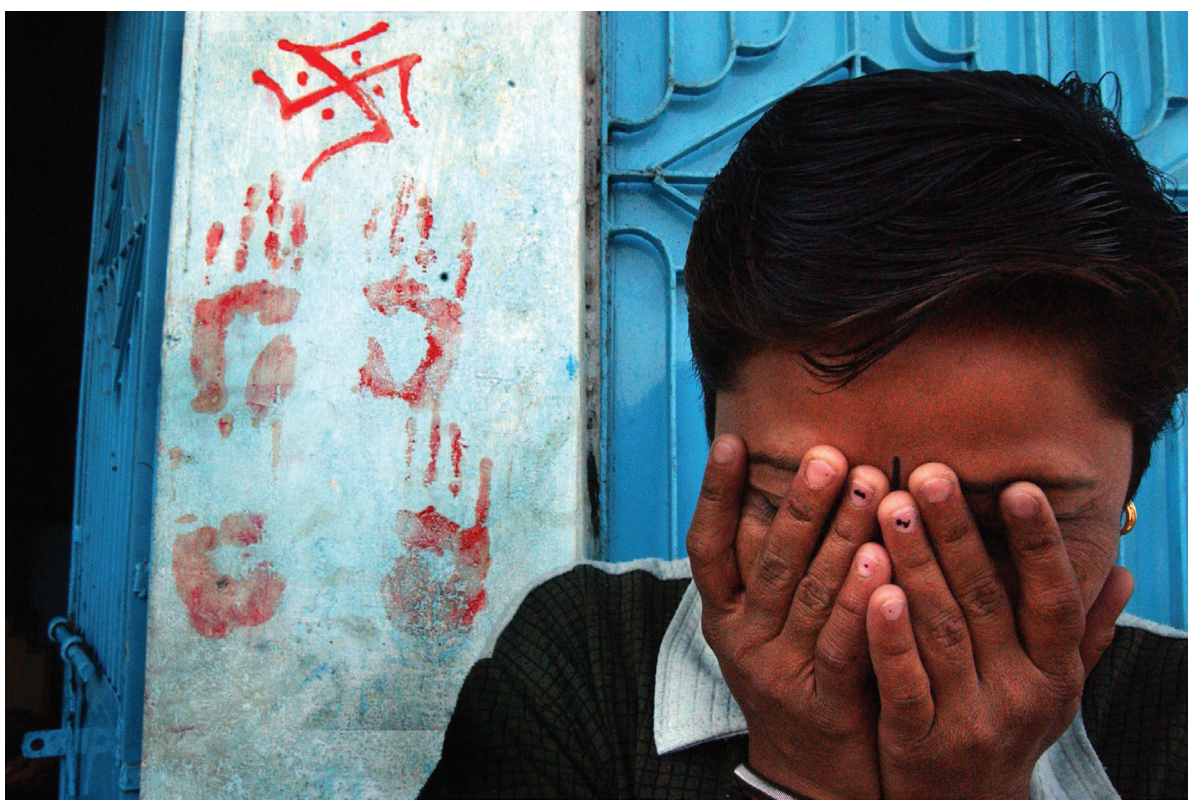

Nisha Rathad, 20, hides her face from the camera in fear, as she stands in front of her house, daubed with bloody graffiti, next door to homes of Muslim neighbors who had been killed the previous day in Ahmadabad, India, March 3, 2002. AMI VITALE / Getty Images

get Muslims, with Home Minister Amit Shah telling reporters in October 2019, "I want to assure all Hindu, Sikh, Jain, Buddhist, and Christian refugees, that you will not be forced to leave India," conspicuously omitting Muslims from the list of protected religions. ${ }^{24} \mathrm{Mr}$. Shah routinely refers to Muslim migrants as 'infiltrators' and 'termites', and has promised to pick them up 'one by one and throw them into the Bay of Bengal. ${ }^{25}$

The Modi government's decision to suddenly revoke Article 370 and $35 \mathrm{~A}$ of the Indian Constitution by stripping Muslim-majority Kashmir of its semi-autonomous status on August 5, 2019, is yet another step towards Hindu nationalists fulfilling their promise to transform India and Kashmir into a Hindu nation. The move has launched Modi's Hindu-settler-colonial project, one mir- roring Israel's illegal colonization of the Palestinian Territories.

In March 2020, the government announced domicile rights for Indian citizens in Kashmir. It has now granted tens of thousands of domicile certificates, which reverse the long-standing law in giving non-locals the right to property ownership and employment. ${ }^{26}$

It is for these reasons that Indian human rights activists and celebrities, including award-winning novelist Arundhati Roy are warning "the situation in India is approaching genocidal," ${ }^{27}$ a view shared also by the world's leading scholar into genocide and ethnic cleansing -Gregory Stanton- who warned in 2020 that "preparation for genocide is definitely underway in India," adding, "the persecution of Muslims in Assam and 
Kashmir is the stage just before the genocide. The next stage is extermination-that's what we call a genocide." ${ }^{28}$

Their respective comments speak to the dramatic spike in hate crimes against Muslims during the Modi era, measured by a 30 percent increase in religious-based hate crimes in the first 3 years of his rule, a rate that has doubled since his re-election in 2019 , with 90 percent of all religious hate crimes in the decade spanning 2010 to 2020 occurring since Modi came to power; ;9 $^{29}$ Muslims the target of 78 percent of these hate crimes; and more than two-thirds of anti-Muslim hate crimes occurring in states ruled by BJP. ${ }^{30}$

A study conducted by the University of Massachusetts, Amherst found a direct correlation between the number of hate crime incidences and the share of the total vote BJP received in the 2014 national election by comparing religiously motivated hate crime data from the pre-election period from 2009 to 2013 with post-election period from 2014 to $2019 .{ }^{31}$ In Uttar Pradesh, for example, where BJP received 42 percent of the total vote, hate crimes spiked almost 2000 percent in the post-election period, from 2 to 45 incidences. In Rajasthan, BJP received 55 percent of the total vote and recorded a 1,000 percent increase in the post-election period, from two to 20 incidences.

In increasing frequency and ferocity, Muslims are threatened, lynched, beaten, raped, and murdered, and their homes, businesses, and mosques vandalized and attacked. Worryingly, human rights groups have observed an increasing trend in which the police and judiciary sides with the Hindu perpetrator, and dismisses or even threatens the Muslim victim, thus creating a permissive environment for anti-Muslim violence. Researchers have shown that Indian security forces "identify with structures of majoritarian nationalism to enact violence." 32

The 2019 ruling by India's Supreme Court in favor of Hindu nationalists who destroyed the $16^{\text {th }}$ century Babri Mosque in 1992 is the culmination of BJP's effort to chip away at the rights of Muslims in the judiciary, and thus reaffirming their status as second-class citizens in a supposedly secular democratic country. ${ }^{33}$

This rising animosity and violence towards Muslims by the Hindu majority population reached a zenith over six bloody days in New Delhi during February 23-29, 2020, when more than 50 Muslims were murdered after a BJP leader gave a speech urging supporters to attack anti-CAA protesters.

"The Mohammadan was running. The Hindu public was chasing him. I was leading the pack. I was the first to catch up with him and hit him with my rod on his head, then he fell down, and the public pounced on him after that," a Hindu man, who claimed to have murdered 3 Muslims, told an Indian journalist. ${ }^{34}$

An investigation by an Indian based human rights commission concluded 
that the violence was not only incited by the BJP leader but also that Delhi Police officers participated in attacks against Muslims, as "armed mobs chanting [Hindu] slogans selectively attacked Muslim individuals, houses, shops, vehicles, mosques, and other properties." ${ }^{35}$

Disturbingly, there's been little action taken against the perpetrators and zero action against Delhi Police, as observed by human rights group Amnesty International, which warns: "This ongoing state-sponsored impunity sends the message that the law enforcement officials can commit grave human rights violations and evade accountability. That they are a law unto themselves." ${ }^{36}$

The Delhi riots have also done nothing to discourage BJP politicians, RSS leaders, and pundits in the mainstream media from referring to Muslims in dehumanizing and genocidal terms, a reality that has become measurably worse during the COVID-19.

Whereas Muslims were once demonized as a foreign threat, such as 'Pakistanis' or 'terrorists', the arrival of the virus has them increasingly portrayed as a threat from within, with Hindu nationalist groups spreading rumors and conspiracies about the virus not being naturally occurring but as a sinister plot by Muslims to deliberately infect the Hindu population. ${ }^{37}$

When the country's initial outbreak of the COVID-19 emerged among foreign missionaries attending an Islamic conference hosted by Tablighi

\section{Hindu nationalists spread}

conspiracy theories about

COVID-19 being a secret

'Muslim plot,' with the hashtag

\#CoronaJihad going viral

across an array of social media

\section{platforms}

Jamaat in March 2020, ${ }^{38}$ Hindu nationalists spread conspiracy theories about COVID-19 being a secret 'Muslim plot', with the hashtag \#CoronaJihad going viral across an array of social media platforms.

Fake news stories of Muslims deliberately spreading the virus by spitting on food, restaurant utensils, and passers-by were liked and shared by millions of social media users, as were caricatures of 'Muslim terrorists' wearing the virus instead of a suicide vest, and the virus dressed up in Islamic clothing. ${ }^{39}$ These fake stories, conspiracies, and social media memes were picked up and amplified by right-wing media outlets, causing an almost hysterical fear and hatred of Muslims among the Hindu population, which unsurprisingly "led to an increase in incendiary hate speech, false claims, and vicious rumors intended to encourage violence and ostracize the Indian Muslim community." ${ }^{40}$ This prompted the Organization of Islamic Cooperation (OIC) to express concern on April 19, 2020 about "anti-Muslim sentiments and Islamophobia within political and 
warned Muslims under his rule that their 'funerals will begin' if their quest to marry Hindu women didn't end. ${ }^{45}$ It is unsurprising that a handful of Muslims have since been lynched in Uttar Pradesh by 'Love Jihad' vigilantes, who now enjoy the implicit support of the state. ${ }^{46}$

Laws excluding Muslims from marrying Hindus replicate the Nazi Party's Nuremberg Laws enacted in 1935 , which prohibited Jews from marrying or having sexual relations with persons of 'German blood.'47 History records that the concentration camps and 'Final Solution' soon followed.

That the Modi government and it's Nazi Party-inspired sidekick RSS have taken steps towards the Nazification of India's laws and institutions points to a continuing upward surge of violence against the country's 200 million Muslims.

\section{Endnotes}

1. Manoj Mitta, The Fiction of Fact-Finding: Modi and Godhra, (Harper Collins, 2015).

2. Aditya Chakrabortty, "Narendra Modi, a Man with a Massacre on His Hands, It Not the Reasonable Choice for India," The Guardian, (April 8, 2014), retrieved from https://www.theguardian. com/commentisfree/2014/apr/07/narendra-modi-massacre-next-prime-minister-india.

3. Anosh Malekar, "Silence of the Lambs," The Week, (April 7, 2002).

4. Shah Alam Khan, "Babu Bajarangi's Bail Mars the Idea of Justice," The Wire, (March 16, 2019), retrieved from https://thewire.in/law/babu-bajrangi-bail-idea-of-justice.

5. Janyala Sreenivas, "Who Shot Them Point Blank?" Indian Express, (April 7, 2002).

6. "We Have No Orders to Save You: State Participation and Complicity in Communal Violence in Gujarat," Human Rights Watch, (April 2002), retrieved from https://www.hrw.org/reports/2002/ india/India0402-03.htm\#P486_86937.

7. Annie Gowen, "Once Banned from the US, Modi Set for Historic Address to Congress," The Washington Post, (June 6, 2016), retrieved from https:// www.washingtonpost.com/news/worldviews/ wp/2016/06/06/from-pariah-to-capitol-hill-narendra-modis-extraordinary-rise/.

8. Rami Lakshmi, “US Denies Visa to Indian Hindu Nationalist," The Washington Post, (March 19, 2005), retrieved from https://www.washingtonpost.com/news/worldviews/wp/2013/07/23/ indian-politicians-ask-obama-to-deny-a-visa-toone-of-their-own/.

9. Ritesh Kumar Singh, "Narendra Modi Has Left India's Economy a Shattered Mess," Nikkei Asia, (August 31, 2020), retrieved from https://asia.nikkei.com/Opinion/Narendra-Modi-has-left-Indias-economy-a-shattered-mess.

10. Amrita Basu, Violent Conjunctures in Democratic India, (New York: Cambridge University Press, 2015).

11. Hartosh Singh Bal, "How an Inability to Stomach Gandhi's Overtures to Muslims Led Hedgewar to Set Up the RSS," The Caravan, (June 10, 2018), retrieved from https://caravanmagazine. in/politics/hedgewar-rss-founded-gandhi-overture-muslims.

12. Marzia Casolari, In the Shadow of the Swastika: The Relationships between Indian Radical Nationalism, Italian Fascism and Nazism, (Routledge, 2020), p. 110.

13. Srenick Rao, "Hitler's Hindus: The Rise and Rise of India's Nazi-Loving Nationalists," Haaretz, (December 15, 2017), retrieved from https://www. haaretz.com/opinion/hitlers-hindus-indias-nazi-loving-nationalists-on-the-rise-1.5628532.

14. CJ Werleman, "Hitler: Inspiring Hindu Nationalists to Kill Muslims, Extra News Feed, (January 20, 2018), retrieved from https://extranewsfeed.com/ hitler-inspiring-hindu-nationalists-to-kill-muslims-db70d2d74cef.

15. Rao, "Hitler's Hindus."

16. Piyush Srivastava, "We Will Free India of Muslims and Christians by 2021: DJS Leader Vows to Continue Ghar Wapsi Plans and Restore Hindu Glory," Daily Mail, (December 19, 2014), retrieved from https://www.dailymail.co.uk/indiahome/ indianews/article-2879597/We-free-India-Muslims-Christians-2021-DJS-leader-vows-continueghar-wapsi-plans-restore-Hindu-glory.html. 
17. “BJP Leader Threatens Muslims to Vote for BJP in Barabanki," National Herald, (November 17, 2017), retrieved from https://www.nationalheraldindia.com/national/bjp-leader-threatensmuslims-to-vote-for-bjp-in-barabanki.

18. "Do Not Buy From Muslims: BJP Leader in India Calls for Boycott, Al Jazeera, (April 29, 2020), retrieved from https://www.aljazeera.com/news/ 2020/4/29/do-not-buy-from-muslims-bjp-leader-in-india-calls-for-boycott.

19. CJ Werleman, "An Apartheid Era Begins in India, As Does a Moral Dilemma for Its Allies," Byline Times, (April 23, 2020), retrieved from https:// bylinetimes.com/2020/04/23/an-apartheid-erabegins-in-india-as-does-a-moral-dilemma-for-itsallies/.

20. "Shoot the Traitors: Discrimination against Muslims Under India's New Citizenship Policy," Human Rights Watch, (April 9, 2020), retrieved from https://www.hrw.org/report/2020/04/09/ shoot-traitors/discrimination-against-muslimsunder-indias-new-citizenship-policy.

21. "Shoot the Traitors: Discrimination Against Muslims Under India's New Citizenship Policy."

22. Jeffrey Gettleman and Hari Kumar, "India Plans Big Detention Camps for Migrants. Muslims Are Afraid," The New York Times, (April 17, 2019), retrieved from https://www.nytimes.com/2019/08/ 17/world/asia/india-muslims-narendra-modi. html.

23. "India Plans Big Detention Camps for Migrants. Muslims Are Afraid."

24. "Shoot the Traitors: Discrimination Against Muslims Under India's New Citizenship Policy."

25. Devjyot Ghoshal, "Amit Shah Vows to Throw Illegal Immigrants into Bay of Bengal," Reuters, (April 13, 2019), retrieved from https://www.reuters.com/article/india-election-speech-idUSKCN1RO1YD.

26. "J\&K Govt Has Issued 17 lakh Domicile Certificates, Even to Those Without Permanent Resident Certificates," National Herald, (September 16, 2020), retrieved https://www.nationalheraldindia. com/india/jandk-govt-has-issued-17-lakh-domicile-certificates-even-to-those-without-permanent-resident-certificates.

27. John Silk, "Novelist Arundhati Roy Claims Pandemic Exposes India's Ccrisis of Hatred against Muslims," DW, (April 19, 2020), retrieved from https://www.dw.com/en/arundhati-roy-claimscoronavirus-exposes-indias-crisis-of-hatredagainst-muslims/a-53167812.
28. "Muslims in Kashmir, Assam 1 Step Away from Extermination: Genocide Researcher," The Week, (December 14, 2019), retrieved from https://www. theweek.in/news/world/2019/12/14/muslimsin-kashmir-assam-1-step-away-from-extermination-genocide-researcher.html.

29. Harsh Mander, "New Hate Crime Tracker in India Finds Victims Are Predominantly Muslims, Perpetrators Hindus," Scroll, (November 13, 2018), retrieved from https://scroll.in/article/901206/newhate-crime-tracker-in-india-finds-victims-arepredominantly-muslims-perpetrators-hindus.

30. "New Hate Crime Tracker in India Finds Victims Are Predominantly Muslims, Perpetrators Hindus."

31. Deepankar Basu, "Dominance of Majoritarian Politics and Hate Crimes Against Religious Minorities in India, 2009-2018," UMass Amherst Economics Working Papers, (December 2, 2019), retrieved from https://scholarworks.umass.edu/ econ_workingpaper/272/?_gl=1*15pg818*_ga* MTI wNDM 1 NTU 5OC 4xNjIxMjQ2MDEw* ga_21RLSOL7EB*MTYyMTIONjAwOS4xLjEuMTYy MTIONjAOMC4w\&_ga=2.74270162.1360997307. 1621246010-1204355598.1621246010.

32. Srinath Jagannatha, Rajnish Rai, and Christophe Jaffrelot, "Fear and Violence as Organizational Strategies: The Possibility of a Derridean Lens to Analyze Extra-Judicial Police Violence," Springer Link, (October 20, 2020), retrieved from https:// www.springerprofessional.de/en/fear-and-violence-as-organizational-strategies-the-possibility-o/18505486.

33. Aarti Betigeri, "Ayodhya Verdict and Unruly Consequences," The Lowy Institute, (November 15, 2019), retrieved from https://www.lowyinstitute. org/the-interpreter/ayodhya-verdict-and-unruly-consequences.

34. "Meet Delhi Rioters Who Claim They Killed Muslims," The Express Tribune, (March 5, 2020), retrieved from https://tribune.com.pk/story/2170 108/9-meet-delhi-rioters-claim-killed-muslims.

35. "BJP Leaders Incited People: Delhi Minorities Commission's Report on February Riots," Outlook India, (July 17, 2020), retrieved from https:// www.outlookindia.com/website/story/indianews-bjp-leaders-incited-people-delhi-minorities-commissions-report-on-february-riots/356856.

36. "Six Months Since Delhi Riots, Delhi Police Continue to Enjoy Impunity Despite Rights Violations," Amnesty International, (August 27, 2020), retrieved from https://www.amnestyusa. org/press-releases/six-months-since-delhi-ri- 
ots-delhi-police-continue-to-enjoy-impunity-despite-rights-violations/.

37. Shweta Desai and Amarnath Amarasingam, "\#CoronaJihad: COVID-19, Misinformation, and Anti-Muslim Violence in India," ISD Global, (November, 2020), retrieved from https://strongcitiesnetwork.org/en/wp-content/uploads/sites/ 5/2020/05/CoronaJihad.pdf.

38. "Tablighi Jamaat: The Group Blames for New Covid-19 Outbreak in India," BBC News, (April 2, 2020), retrieved from https://www.bbc.com/ news/world-asia-india-52131338.

39. Fahad Nabeel and Maryam Raashed, "The Hindutva Aspect of COVID-19 Outbreak in India," Centre for Strategic and Contemporary Research, No. 11 (June 10, 2020), retrieved from https:// www.researchgate.net/publication/342105142_ The_Hindutva_Aspect_of_COVID-19_Outbreak_ in_India.

40. Desai and Amarasingam, "\#CoronaJihad."

41. Anna MM Vetticad, "Indian Media Accused of Islamophobia for Its Coronavirus Coverage," Al Jazeera, (May 15, 2020), retrieved from https:// www.aljazeera.com/news/2020/5/15/indian-media-accused-of-islamophobia-for-its-coronavirus-coverage.

42. Desai and Amarasingam, "\#CoronaJihad."

43. Zeenat Saberin, "Hate Crime in India: Muslim Man Hacked, Burned to Death," Al Jazeera, (December 7, 2017), retrieved from https://www. aljazeera.com/news/2017/12/7/hate-crime-in-india-muslim-man-hacked-burned-to-death.

44. "Yogi's Love Jihad Warning: 'Your Ram Naam Satya Journey Will Begin if You Don't Mend Ways," The Indian Express, (October 31, 2020), retrieved from https://indianexpress.com/article/cities/ lucknow/yogi-adityanath-love-jihad-law-uttar-pradesh-6911537/.

45. "Yogi's Love Jihad Warning."

46. CJ Werleman, "LOVE JIHAD: Another Step Towards India's Nazification," Byline Times, (November 23, 2020), retrieved from https://bylinetimes. com/2020/11/23/love-jihad-another-step-towards-indias-nazification/.

47. Werleman, "LOVE JIHAD." 


\section{SETA}

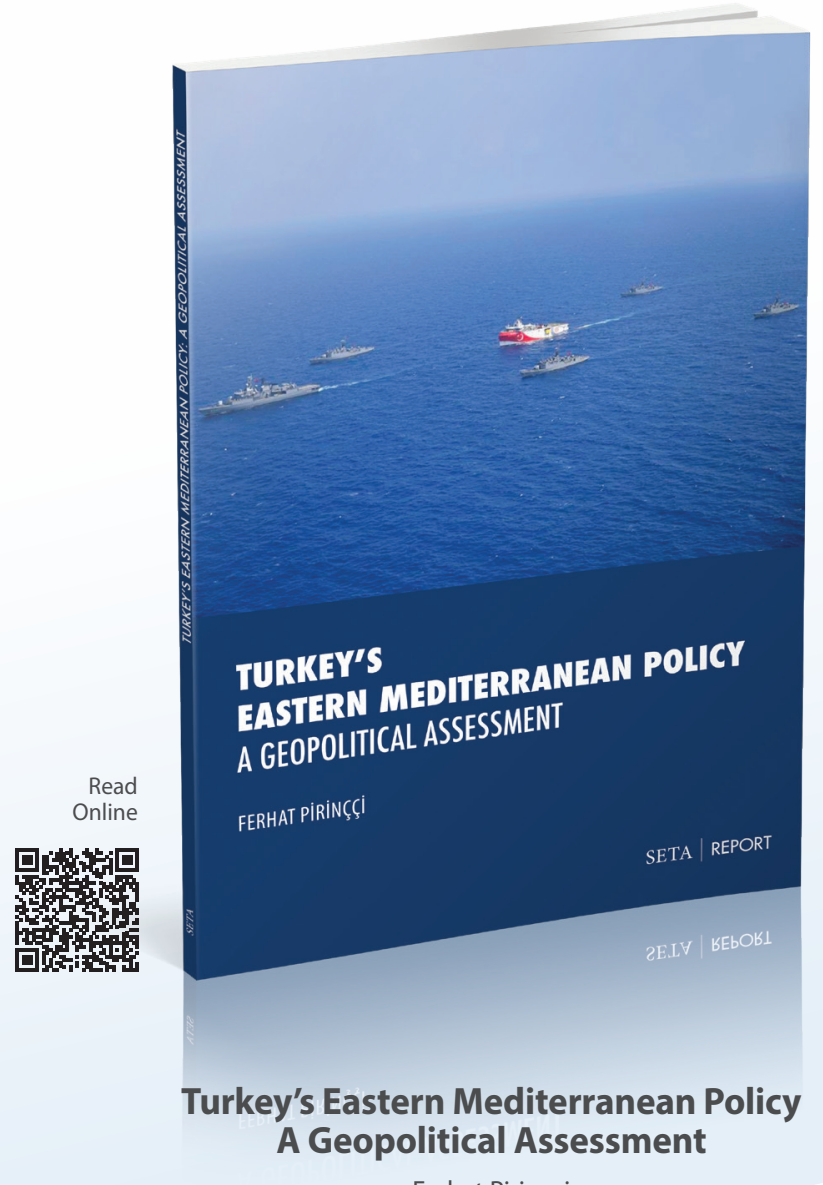

Ferhat Pirinççi

This study analyzes Turkey's Eastern Mediterranean policy and tries to define the priorities and dimensions of the geopolitical struggle in the Eastern Mediterranean as a response to recent approaches to reduce the definition and frame of Turkey's Eastern Mediterranean policy. Turkey's Eastern Mediterranean policy cannot be confined exclusively to the Greece-Turkey relations, Cyprus, the concept of "Blue Homeland", or the hydrocarbon reserves. The study opposes such a reduction of it and asserts that the Turkey's Eastern Mediterranean policy should be addressed from a broader perspective which includes all of the above, but is not limited to them. 